The Hong Kong Journal of Social Work

Vol. 51, No. 1/2 (Summer/Winter 2017) 93-114

(C) World Scientific Publishing Company

Hong Kong Social Workers Association

DOI: $10.1142 / \mathrm{S} 0219246217000079$

\title{
SOCIAL RETURN ON INVESTMENT FOR COMMUNITY-BASED ENTERPRISE IN SURABAYA CITY
}

\author{
ALUISIUS HERY PRATONO \\ SUYANTO \\ DEDDY MARCIANO \\ Universitas Surabaya, Indonesia \\ CHRISTIAN ZURBRÜGG \\ Eawag, Switzerland
}

\begin{abstract}
This study aims to examine the social impact of a community-based enterprise model in Surabaya City. The analysis focuses on grass-root communities and highlights some technical challenges in order to develop a meta-theory with the intention of examining the underlying assumptions of the social return on investment. The social impact analysis is based on a social return on investment (SROI) approach, which involves community participation through focus group discussions. To avoid complexity, this study focuses on one year's activities, which attributed monetary values to the social impact. It is argued in this study that the green and clean activities provide a return of 1.23 on the investment. This result demonstrates how the community-based social enterprise is feasible in achieving appropriate support. First, this study focuses on the community perspective during the observed time. The communities may experience different levels of capability and resources that contribute to the achievement of the programme. Secondly, there is a lack of literature that could provide financial analysis and there is no common accepted method for measuring the value of the social benefits. Beyond the SROI computation, this study highlights some technical challenges and misconceptions involved in measuring the social return on investment (SROI). Although there is considerable information available about the conceptual framework of SROI, there is great variability in how SROI is applied across interventions. This makes robust and consistent comparisons across social ventures difficult, while rendering the validity of SROI measures vulnerable to being contested.
\end{abstract}

Keywords: Social return on investment; social enterprise; community-based waste management. 


\section{Introduction}

The willingness to contribute to development projects has been considered as commitment and sustainability, but there is little evidence for this belief (Masuri \& Rao, 2013). Social impact assessment plays a pivotal role not only in monitoring performance, but for resource acquisition, mission reinforcement and general stakeholder accountability (Pathak \& Dattani, 2014). This provides power to those affected by the work of an organization.

The Surabaya Green and Clean Festival has encouraged the local communities in Surabaya City, Indonesia to develop their neighborhood environment. The community-based waste management in Surabaya was routinely advocated in national strategies as the best model for a decentralization policy (Bunnell, Miller, Phelps, \& Taylor, 2013). Local communities do not only collect their own solid waste, but also become involved in promoting the local culture, compost industry and creative industry. However, there was previously no attempt to indicate the benefit from these social investments.

The views on how the program may improve the social benefits for consumers and the kinds of changes to policy and practice that matter to citizens is crucial in evaluating the success of community participation (Nathan, Braithwaite, \& Stephenson, 2014). It appears that the process of social change is very complex and it often demands time, resources and effort from the members of a society, which is not always appreciated (Andersén \& Andersén, 2014). Any approach to measuring social impact that does not involve a transfer of power to stakeholders should be considered as an advertising approach instead of a social change (Nicholls, 2014).

This study demonstrates the evaluation of Green and Clean activities from the perspective of the Surabaya community members. The social impact analysis is based on a social return on investment (SROI) approach, which involves interviews, observation and a literature review. To understand the essence of SROI, the study focuses on the perspective of local communities. Hence, the analysis will consider some attributes of SROI, such as deadweight, displacement, drop off, attribution and discount rate.

\section{Literature Review}

Over the decades, the term "social innovation" has overtaken the term "social entrepreneurship" (Paunescu, 2014). Schumpeterian argues that the initiative change from individuals is necessary for social evolution and economic development through a process of creative destruction (Michaelides \& Theologou, 
2010). Social innovations refer to innovative products or services with the aim of meeting a social need, with the opportunity to create new social relationships or collaborations (Altuna, Contri, Dell'Era, Frattini, \& Maccarrone, 2015).

The social exchange theory highlights that participation springs from the individual cost-benefit analysis (Kashif, Sarifuddin, \& Hassan, 2015). The mechanism of community participation involves the exchange of ideas, resources and values among various stakeholders, i.e., public, private, and non-profit making sectors. This impacts on the shifting relationships between business, government and non-profits as well as the blending of market-based principles and mechanisms with public and philanthropic support (Phills, 2008).

The reciprocity in community participation pertains to social commitment, which is contingent on the exchange (Slack, Corlett, \& Morris, 2015), which involves long term relationships among the community members, either individuals or corporate groups, acting as single units (Tanskanen, 2015). As the community participation has undergone several episodic changes and secured long-term wellbeing, there is a risk of the relationship failing (Devezer, Sprott, Spangenberg, \& Czellar, 2014). Resistance and negative representations of the pre-change situation are likely to occur despite the communities experiencing a positive social impact (Andersén \& Andersén, 2014).

The causes of innovation in alliance with others can be refusals by existing institutions and enterprises to take up innovations despite it bringing negative consequences for their customers, clients or patients, while success depends on the courage of the client to go beyond what they know and to take their organization with them (Boxer, 2015). Peer support is essential for social investment, which provides social benefits for the targeted group as well as for the volunteers who support the groups (Willis, Semple, \& de Waal, 2016).

It was evident that social identity construction involves a continuous evolving process that lends the requisite dynamism to the relationships which impacts on how an organization's identity can developed over time, as the multiple social identity process of the stakeholders changes (Jacobs, 2013). A long-term contract is essential to promote normal commitment to change, as employees and volunteers with higher relational attachment to the changing organization are likely to be more willing to bear imminent sacrifices for the prospect of future returns (Jing, Xie, \& Ning, 2014).

Turning to social investor or socially responsible investment, investor perception emphasizes on business's environmental performance and environmental impact (Berry \& Junkus, 2013). Investors are encouraged to rank firms in order to anticipate larger future cash flows due to more positive reactions from key stakeholders, such as environmentally conscious customers, employees, NGOs 
and regulators (Cordeiro \& Tewari, 2015). In the Indonesian context, religious organizations have been emerging with support from various stakeholders, including government and civic society (Pratono \& Sutanti, 2016).

Social investment expects both a social outcome and a financial return, which would usually be below the market rate (Kurtz \& diBartolomeo, 2011). For voluntary organizations, this represents a form of repayable finance that can be used for capital investment, revenue funding development, capacity building or other ways of improving sustainability. In the European context, social policy scholars warn that the shifting emphasis of social policy towards social investment in human capital policies and labor market integration, may well come at the expense of social protection and inclusion for all (Deeming \& Smyth, 2015).

The decentralization of public policy aims to fill the gap between decision makers and communities through promoting participation. Organizing communities to solve market and government failures is subject to problems of coordination, asymmetric information and pervasive inequality (Masuri \& Rao, 2013). However, this policy raises a paradox, as extraordinary proliferation of participation initiative lessens the ability of the state to threaten local elites (Faguet, 2014).

The effort to promote cooperative values in the community is associated with the concept of social capital theory, which states that social exchange relationships should rely on interpersonal trust (Kwon \& Adler, 2014). Trust is an essential element for any organization to deal with uncertainty (Milanov \& Shepherd, 2013). High levels of trust show the high quality of the exchange relationship that brings access to information, support and resources (Schaubroeck, Peng, \& Hannah, 2013). Hence, the effort needs to take into account a tailored message to deal with the risk of messenger bias in the persuasion context (Ludwig, de Ruyter, Friedman, Brüggen, Wetzels, \& Pfann, 2013).

\section{SROI}

According to the social exchange theory, the real benefit is the main reason why community members are more likely to participate in a development program, such as waste management (Osrom, 2009). Social Return on Investment (SROI) provides a framework for measuring the social impact of a community development programme by incorporating social, environmental and economic costs and benefits. SROI tells the story of how change is being created by measuring social, environmental and economic outcomes and uses monetary values to represent them (Nicholls, 2014).

Derived from analytical methods such as cost-benefit analysis and social accounting, SROI should provide information so that stakeholders can hold 
organizations to account (Willis, Semple, \& de Waal, 2016). There are four original principles underlying the philosophy of social impact assessment: the precautionary principle; the intergenerational equity; the multi-sector integration and subsidiarity (Taylor \& Bradbury-Jones, 2011).

The combination of voluntary multi-stakeholder and open government reform is an essential part of social accountability to meet the expected social and environmental standards (Fox, 2014). The approach involves community participation to monitor and oversee the performance of the implemented project. The analysis needs to identify the stakeholders and report the value in a comparable, verifiable, timely and understandable way to meet the high level of integrity in stakeholder valuing (Carlon \& Downs, 2014).

The SROI analysis relies upon the use of assumptions, which relate to impact, outcome valuation, attribution and drop-off. There is a great variance in the application of assumptions and inputs in many of the SROI analyses, and these introduce a sufficient element of subjectivity that makes a comparison across SROI figures problematic (Pathak \& Dattani, 2014).

As a normative ethical approach, social valuation must be completed, neutral and free from error. However some cases only value the positive effects and ignore the negative (Carlon \& Downs, 2014). This will defeat the purpose of stakeholder valuation and could halt any progress being made in the evolution of stakeholder theory. To establish credibility and critical thinking, the analysis should present the assumptions and rationales for making judgements at every stage (Arvidson, Battye, \& Salisbury, 2014). Without this, the degree of institutional and administrative change required will be difficult to achieve (Jardine \& Whyte, 2013).

\section{The Social Enterprise}

The initiative to introduce a community-based recycling programme occurred in 2004. The first pilot project waste management system was in Rungkut Lor, a low-income neighborhood (Premakumara, 2012). KITA, under financial support from the Japan Fund for Global Environment of the Environmental Restoration and Conservation Agency, started work with Pusdakota, a local non-government organization at the University of Surabaya and introduced a community-based waste recycling program. What has been referred to as the "Takakura magical box" was promoted by the city government and distributed by an NGO, while the city government also established some sixteen community-based composting centers. 
In 2005, the Green and Clean Campaign began with a series of media-backed neighborhood competitions. This was successful in motivating neighborhood groups to clean up their local environment and reduce waste at source by practising waste segregation and composting. Between 2005 and 2008, Surabaya City had reduced the waste from 1,500 to 1,150 tons per day. The Government introduced the $3 \mathrm{R}$ program: reduce, reuse and recycle. The pilot projects encouraged the local communities to run community-based enterprises. Compost became the main product for the state-societal partnership.

The competition was successful in motivating the communities. Award-winning communities became visible through newspaper and TV coverage. The community intended to clean up their environment and reduce waste (Bunnell, Miller, Phelps, \& Taylor, 2013). In 2009, around 30\% of all neighborhood units (Rukun Tetangga or $R T$ ) in the city ran the community-based waste management model.

\section{Method}

To analyze the impact of the Green and Clean competition, this study is retrospective and based on actual outcomes from the perspective of local communities. The source of data comes from stakeholder interviews and focus group discussion with the aim of seeking the costs and benefits from their perspective. The stakeholder analysis concerns their experience and the changes related to the activity in the Green and Clean Competition.

The unit analysis is a group from the community, locally called RT which stands for "Rukun Tetangga". Information was initially collected from the head of RT, who was awarded the best performance on the green and clean competition. The leader's wife was appointed as a community organizer for female activists of the PKK (Family Welfare Program).

To analyze the data, this study asked stakeholders to put a monetary value on their deployed resources and its impact. The analysis relied upon the use of assumptions that stakeholders understand the social benefit as well as the deployed resources to support the programme. Hence, observation was carried out on the basis of communities who achieved the best performance at the competition. They came from Gundih, Jambangan, Demak, Penjaringan, Dukung Setro, Mojo Gubeng and Rungkut Lor. 
Table 1. Research participants

\begin{tabular}{lcccc}
\hline \multicolumn{1}{c}{ Villages } & $\begin{array}{c}\text { Local } \\
\text { leaders }\end{array}$ & $\begin{array}{c}\text { Community } \\
\text { members }\end{array}$ & Volunteers & Others \\
\hline Penjaringan & 1 & 4 & 1 & \\
Candi Rejo & 2 & 1 & 2 & 1 civil servant \\
Gundih Barat & 1 & 4 & - & 1 local trader \\
Mojo Gubeng & 1 & 5 & - & \\
Demak Timur & 3 & - & 3 & \\
Lembah Wiyung & 1 & 1 & - & 1 health worker \\
Gunung Anyar & 1 & 3 & - & \\
Kapas Gading Madya & 1 & - & 3 & \\
Gundih Timur & 1 & 3 & - & \\
Jambangan & 1 & 1 & 3 & 3 \\
Total & 13 & 22 & 13 & \\
\hline
\end{tabular}

\section{Formula}

The SROI formula measures the value of social benefit relative to the social cost. This demonstrates a ratio of the net present value of the benefit to the net present value of the social investment (Rotheroe \& Richards, 2007). The framework presents the social impact of the community-based waste management program.

$$
S R O I=\frac{\text { Net present value of benefits }}{\text { Net present value of investments }}
$$

\section{Assumption}

This study considers some concepts and assumptions, which brought about the major analysis.

- Social impact. Apparently, the community-based waste management was expected to have an immediate and direct impact on certain people, but it can also have a more far reaching effect on people, organizations, institutions and entities who are not directly engaging in it. This study focuses on the direct impact on the observed communities, who became involved in the activities.

- Outputs. The evaluation captured the outputs, which include the numbers of support or service interactions that women, children and other community members received while they were involved in the waste management 
during the year. Documenting outputs consists of counting the number and types of services that the participants receive, including the length of time each participant remained in the program (e.g., number of days in the training activities); and the frequency with which the community members used particular services (e.g., number of group sessions attended).

- Outcome valuation. The analysis included outcomes, which represent the change as a result of the participation in the program. The outcome was expected to clearly identify the type of change that was measured and ensure that proposed outcomes were achievable. Outcomes should make sense in the context of the needs of the community members served by the program, and, although these can be challenging to measure in one year, there are a number of standard outcomes most community members seek to accomplish.

- Attribution. This concept takes account of the fact that outcomes were also influenced by other projects. It appears that the activities required strong social capital, which came from various activities. Female played a pivotal role in the community. Prior to the waste management program, they had various activities, including a community-based rotating saving and credit association. Other social and religious activities also needed to be taken into account. For example, most of the observed communities experienced annual activities to clean up their environment, which is part of the Independence Day celebrations.

- Deadweight, the outcome that appears even if there was no project activity. If there was no project, the observed communities had to pay for the cost of the waste collection, the cost of the facilitating team building, the cost for visiting health services, the cost for an in-clinic parenting program and the cost for family therapy sessions.

- Drop off is associated with how the outcome will change over time. This SROI analysis focused on value estimation in a realistic one-year observation. The measure assumed that investment and benefit occurred in the one year of observation. The result might come from the social investment at a previous time.

- The research participants were assumed to understand the context and be well informed on the financial issues.

\section{Findings}

Based on interviews and group discussions, this study provides a list of inputs, a list of outcomes and financial proxies. Here are the explanations behind each value. 


\section{The Input}

The efforts to promote the community engagement by having a competition to promote waste management focused on separating organic waste from non-organic waste, composting, community gardening and folk dance training activities. A number of neighborhood meetings were arranged to call for support from the community. This group was comprised of people who felt committed to the recycling program, creation of the gardens and had the time to devote to it (Table 2).

Table 2. The inputs

\begin{tabular}{|c|c|c|c|}
\hline Input & & Financial proxy & Value \\
\hline \multicolumn{4}{|c|}{ Voluntary } \\
\hline 1. & Voluntary community organiser & $\begin{array}{l}\text { The average salary for NGO staff was } \\
\text { IDR } 3,200 \text { per month. }\end{array}$ & 38,400 \\
\hline 2. & Voluntary recycling training & $\begin{array}{l}\text { Cost for two days training activity with a } \\
\text { local trainer. }\end{array}$ & 6,000 \\
\hline 3. & Voluntary solid waste collectors & $\begin{array}{l}\text { Annual salary for a professional waste } \\
\text { collector in other communities. }\end{array}$ & 12,000 \\
\hline 4. & Voluntary gardeners & $\begin{array}{l}\text { Annual salary for a gardener in other } \\
\text { communities. }\end{array}$ & 18,000 \\
\hline \multicolumn{4}{|l|}{ Cost } \\
\hline 5. & Cost for planting trees. & $\begin{array}{l}\text { The annual expenditure was averaged out } \\
\text { at about } 500 \text { per household. }\end{array}$ & 50,000 \\
\hline 6. & Cost for a Takakura basket & $\begin{array}{l}\text { Each family needed a basket, which cost } \\
\text { them } 100 \text { per basket. }\end{array}$ & 10,000 \\
\hline $\begin{array}{l}7 . \\
\text { landfill }\end{array}$ & Cost for renting a processing & The land rented for 8,000 per annum. & 8,000 \\
\hline \multicolumn{3}{|c|}{ Total Cost } & 142,400 \\
\hline
\end{tabular}

Note: A community with one hundred family members in one year (in IDR 000).

1. Voluntary community organizer. Organizing the community is a key element to the success of community-based waste management. The observed communities confirmed the role of a local community organizer, who not only held community meetings, community gardening, community waste management but also gained support from government and private sectors. The community meetings were conducted at various stages, preferably during the project conceptual stage and prior to the competition. In the 
early stages, the local leaders and volunteers proposed the development of a recycling facility and supporting activities.

The participants believed that organizing the community stimulated a passion for a strong relationship. Urban areas are associated with individual relationships, which increase hopelessness. This confirmed previous literature, which mentioned that organizing a community brings collectivism, which impacts on reducing hopelessness, while less hopelessness reduced substance use of alcohol and illegal drugs (Du, Li, Lin, \& Tam, 2014). The financial proxy was taken from the local minimum salary standard. The local non-profit organizations also hired their staff on this salary. According to the respondents, this was also acceptable for part-time work as a community leader.

2. Voluntary recycling training. Recycling training for the community was required as a first step. The training acquired some experts and other communities to share their experiences towards waste collection in particular. This included a course on waste management, which was aimed at community leaders with responsibility for ensuring that the recycling process on the site was managed. Acquiring the best practices from other organizations does not only enhance community awareness but also initiates involvement in various stages of neighborhood facilities, from the waste collection process to promoting a social enterprise model. For communities who passed the first round of the Green and Clean competition, the government provided recycling training. Recycling played a pivotal role in the local economy. This resulted in a considerable saving that can be realized through recycling, especially when it avoided the cost of disposal. Following the rising costs associated with transporting waste to the city landfill, the City Government of Surabaya encouraged all communities to recycle their waste. Landfills have limited space. When it was full, the community had to replace it with another landfill, which was generally more expensive, especially in urban areas. The amount was derived from the training cost, which was expected to be around IDR 6,000,000 for annual training activities.

3. Voluntary solid waste collector. Waste collectors played a pivotal role in making sure that the community members separated their garbage collection for recycling. Under the supervision of community leaders, they managed a waste bank. This is a collection point for rubbish. Residents were encouraged to volunteer to be waste collectors. The community members separated their waste into organic and non-organic in return for cash. Organic waste was processed into compost, while non-organic waste was sold based on the categories: plastic, paper, bottles and metal. The 
financial proxy was taken from other communities that hired a professional waste collector. They spent around IDR 1,000,000 as a monthly fee for the waste collectors, who brought the waste to the compost centre. So, the annual expenditure for the collectors was IDR 12,000,000.

4. Voluntary gardener. The success of the Green and Clean competition required gardening skills. Many community members used to be farmers, who came to Surabaya City from a rural area. They were enthusiastic about the green and clean project which enabled them to pursue their gardening hobby. They lived in a small boarding house, these vegetables and flowers were planted with techniques such as the mini wall gardening technique. They also developed a vertiminaponik technique, which allowed them to raise vegetables and fish. The gardening community's activities were carried out after they arrived home and they were able to share their garden's bounty. This activity helped them to save IDR $18,000,000$ per annum for hiring gardeners. The financial proxy was taken from other communities that hired part-time gardeners. They spent around IDR 1500,000 per month for the waste collectors, who brought the waste to the compost center.

5. Cost for planting a tree. A community needs to invest in trees, so the neighborhood becomes green and expands green spaces in the city gardens. The community volunteered to manage various flowers from roses to orchids. The communities bought from the nearby flower market and directly from the farmers, some others brought the trees from their villages. The project attracted more children, especially those who wanted to see the natural food process, which was usually produced in rural areas. On average, a family planted around twenty varieties, including flowers and vegetables. According to the workshop result, the average plant in Surabaya costs around IDR 25,000. Hence, the financial was taken from a community with one hundred members, which spent around IDR 50,000,000 to invest in the various trees.

6. Cost for a Takakura basket. A Takakura basket is an essential tool for a household-based composting process. In order to reduce the waste, the Tatakura basket allowed the community to produce compost on a household scale. To encourage the citizens in Surabaya to compost their own waste in a Takakura basket outside their house, the City Government of Surabaya provided kerbside compost facilities with the Takakura home method at no additional fee. The organic waste was delivered to the landfill compost operation and was offered for sale in the form of compost. The Takakura basket costs around IDR 100,000 per basket. As the study concentrated on a community with one hundred members, the activity cost IDR 10,000 
per community for a year. It was assumed that the lifetime of a basket was one year.

7. Cost for renting a processing landfill. Waste management requires a landfill. This used to be the final resting place for waste, but one landfill for the community-based waste management was quickly turning it into a compost product. Along with support from the Takakura technology, the process of using micro-organisms to break down organic matter was allowed to turn the bio-solids into a stabilized, rich, soil-like substance for fertilizer. It required a space to mix garbage with bio-solids and then to compact this mass which reduces the volume of both the garbage and the bio-solids with a proper ratio. Typically, they found abandoned land. The cost was averaged out at about IDR 8,000,000 for renting a piece of land in Surabaya for one year.

\section{The Impact}

The competition encouraged the communities to come up with various social innovations. In the first round, the communities with a capability to separate their waste were nominated as the winners. The following year, the community with a waste bank became the winner, another community won the prize because they promoted local folk to encourage their community members to get involved in the Green and Clean festival (Table 3).

Table 3. The impact

\begin{tabular}{llc}
\hline & Financial Proxy & Value* $^{*}$ \\
\hline $\begin{array}{ll}\text { Financial income } \\
\text { 1. Income from compost product }\end{array}$ & $\begin{array}{l}\text { Each household sold 5 kg compost per } \\
\text { most, which was priced at IDR4,000 per kg. }\end{array}$ & 20,000 \\
$\begin{array}{ll}\text { 2. Infome from recycled product } \\
\text { perday from paper, plastic, and metal. }\end{array}$ & 60,000 \\
$\begin{array}{l}\text { 3. Financial reward from the Green } \\
\text { and Clean Competition }\end{array}$ & $\begin{array}{l}\text { The financial grant that the Government } \\
\text { awarded. }\end{array}$ & 15,000 \\
$\begin{array}{l}\text { Voluntary activities } \\
\text { 4. Voluntary training other communities } \\
\text { for composting process }\end{array}$ & $\begin{array}{l}\text { Income from ten volunteers from training } \\
\text { activities. They conducted training activity } \\
\text { one in a year }\end{array}$ & 6,000 \\
& &
\end{tabular}

Total

101,000

Note: *: A community with one hundred family members in one year (in IDR000) 
1. Income from the compost product. Organic compost was the main product of this community-development waste management. Compost became a source of income to the observed community, even though the basic principles of waste banks involved behaviour changes, such as collecting waste, earning money, saving money, fulfilling their financial goal, and enjoying a clean neighborhood. However, most of the community used the organic compost for their own gardens. The organic compost was a valuable fertilizer for use in the urban farm, while it was difficult to find a better quality of organic compost at the local market. Along with the Tatakura home method, one family produced five kilograms of organic compost in two weeks or 125 kilograms per annum. Hence, they could earn 625,000 from 125 kilograms per annum. If the family could earn 625,000 , the income from organic compost was expected to be IDR $62,500,000$ per annum at the community level.

2. The observed communities generated income from recycling non-organic products. They managed "waste banks" for collecting non-organic waste. Similar to a commercial bank, the community members were encouraged to open up an account with the waste bank, which would help them to make deposits from non-organic solid waste and convert it into a monetary value. The collectors bought plastic cups or bottles at IDR 900 per kilogram, while plastic bags were half that amount. The group of volunteers who organized the bank in their community were allowed to earn an income of $20 \%$ from the profit, while the rest was for organizational development. The capacity of the waste collection unit was around twenty-eight tons of organic waste and twenty-five tons of inorganic waste per month. The observed community stated that the average income of a bank was IDR $5,000,000$ per month or $60,000,000$ per annum.

3. The observed communities were awarded for their best performance for Green and Clean Kampong. The Green and Clean programme was a competition for communities at various levels, such as new entry, developed and advanced level. The government awarded the Surabaya Green and Clean Award to the communities that met certain environmental criteria, including a novel social innovation. The observed communities said that all the effort had been paid for by an award with a monetary value of IDR $15,000,000$ on average. For example, they were granted IDR $10,000,000$ for a green and clean community and another IDR 5,000,000 for a green and clean art performance.

4. Voluntary training for other communities. Those communities who gained the award of the Green and Clean were invited by other communities. 
They were expected to share their best practices, war stories, swap ideas and other new approaches. Sharing best practice was crucial for the future of the social work as well as for the success of the campaigns on community-based waste management. The best experience has been that the value of these events far outstrips the impact of newsletters, guidance notes, case studies as a means of stimulating new approaches. For training activities, the local NGO charged them around IDR 1,500,000 for a oneday workshop on waste management. In one year of observation, there were four workshops in which they voluntarily gave a speech or shared their best experience. The use of a professional training fee measured as financial for the voluntary training to other communities, which was around IDR 6,000,000 for four activities in one year.

\section{Saved expenditure}

Here is the value that the observed communities preserved by not spending for such consumption. The observed communities said that they saved up for household expenditures in a number of ways (Table 4).

Table 4. Saved expenditures

\begin{tabular}{llr}
\hline & Financial proxy & Value \\
\hline $\begin{array}{l}\text { 1. Saving cost from buying } \\
\text { vegetables }\end{array}$ & Every household used to spend 600 on vegetables. & 60,000 \\
$\begin{array}{l}\text { 2. Saving cost from visiting } \\
\text { health services. }\end{array}$ & $\begin{array}{l}\text { Around 10\% of households used to spend IDR 400 } \\
\text { for the health service per annum. }\end{array}$ & 4,000 \\
$\begin{array}{l}\text { 3. Saving cost from family } \\
\text { counselling }\end{array}$ & $\begin{array}{l}\text { Around 5\% of the observed families had the potential } \\
\text { to get divorced. The community saved the consulta- } \\
\text { tion fee, which was estimated around IDR 2,000. }\end{array}$ & 10,000 \\
\hline
\end{tabular}

Total

74,000

Note: A community with one hundred family members in one year (in IDR 000).

1. Vegetables. Reducing the cost of vegetables. The communities met their vegetable requirements from the urban farming with the aim of promoting a healthy living standard. The observed communities argued that the urban farming activities allowed them to consume vegetables and fruits from their own reliable production process. This program also allowed them to learn how to plant organically in a proper way. These activities did not only encourage the community to establish a waste management system but also a community 
garden, where they grew organic vegetables. The community members felt excited during the harvest time because it meant free vegetables for weeks. They grew the plants, nurtured them and harvested them every two months. The observed community stated that a family spent around IDR 5,000 per day for vegetables, which was equivalent to IDR $1,825,000$ per annum. For a community with one hundred members, this became IDR 182,500,000.

2. Healthy living. Decreasing health expenditure from herbal parks. The gardens were also planted with herbal plants that help to improve the health of residents and reduce the cost of curative care. The RT chiefs were encouraged to act as pioneers by planting herbs, such as ginger to cure colds and influenza, jenggrek ayam to cure insomnia and uterus bleeding and karang nanas to cure coughs and vomiting blood, to help the community transition from the monsoon to the summer season. The financial for living and community herbal garden was derived from saving on visits to the medical clinic, which was around IDR 40,000.

The Indonesia health expenditure per capita was about USD 99 or $2.8 \%$ of total GDP, while the out of pocket expenses for self-medication were $46.95 \%$ of personal spending, which was much higher than the average world rate at $18.2 \%$ (The World Bank, 2015). Along with other national programs such as social security in health (Soewondo, 2014), the Green and Clean competition was expected to help the out of pocket payments to continue declining. Out-of-pocket health care expenditure includes cost-sharing, self-medication, catastrophe and other expenditure paid directly by households (OECD, 2011).

In Surabaya, the number of patients who paid a visit to a community health center was around 12,564 visitors per sub district (BPS Statistic Bureau, 2016). According to the observed communities, dengue fever and diarrhoea were the most common diseases. Medical support at Puskesmas is free because of a subsidy, while the average cost for a visit to a primary care physician was around IDR 70,000. The local residents mentioned that their family spent at least IDR 5 million on medical costs at the hospital for a child who suffered from dengue fever.

3. This program helped the communities to create a new circumstance in the child-parent relationship. Surabaya had the highest divorce statistic record. According to the Supreme Court of Surabaya City, there were 5,996 spouses who sought a divorce and filed a divorce petition in 2015. During the focus group discussion, many housewives stated that they did not feel supported by their families. They argued that their husband preferred to stay at the nearby local café shop overnight, while their children chose to play at the nearby PlayStation center. 
The Green and Clean Festival encouraged each household to venture into producing a small-scale garden. As the community competed to make their neighborhood green, the families spent more time together to manage their garden. They argued that the new environment allowed them to spend more time with their family members. They also become more familiar with their neighborhoods. At one time, they just used to see their neighbors out of their windows. This enhanced a sense of belonging and eased the family conflict.

Some families shared their experiences of dealing with family conflict. That was very costly, as they spent around IDR 2,000 for counselling fees prior to going to court. This cost was confirmed from a local family consultant and as an online counselling fee. Around 5\% of the observed families had the potential to get divorced. If the programme can save $5 \%$ of one hundred families, the community can save around IDR 10,000 for family consultant fees. This assumed that the family problem was solved by a family consultant.

To calculate the SROI, this study divided the net social benefit $(175,000=$ $101,000+74,000)$ by the investment cost $(142,400)$ for a SROI of 1.23 . This demonstrated that the communities had returned a benefit of 1.23 when compared with each dollar spent on the cost.

\section{Discussion}

It is argued in this study that the project provides a return of 1.23 for every IDR 1 invested. Indeed, the monetization is an essential, but not an exclusive one. This result convinces the government, communities and stakeholders that the programme is feasible in achieving the appropriate support. In addition, beyond the SROI computation, this study highlights some technical challenges and misconceptions involved in measuring the impact.

First, there is considerable information available about the conceptual framework of SROI. There is also great variability in how SROI is applied across interventions in different communities. This makes robust and consistent comparisons across social ventures difficult, while rendering the validity of SROI measures vulnerable to being contested.

As this study involves community engagement during the monetary analysis, the most challenging step was placing a financial value through focus group discussion, especially when the literature does not provide a judgment with an appropriate value. The communities may experience different levels of capability and resources that contributed to the achievement of the programme.

It is essential for the stakeholders to understand the impact of community participation as well as the complex debate about the project (Nathan, Braithwaite, 
\& Stephenson, 2014). As stakeholders refer to people or organizations whose experiences account for the change of the community-based management activities (Freeman, Harrison, Wicks, Parmar, \& de Colle, 2010), there was a potential dispute over the data analysis.

Secondly, SROI provides a feasibility measure with a market-based approach, which may encourage the communities to enhance various social innovations, such as community-based waste processing, waste bank model and various social marketing which includes local people. As a consequence, exaggerating the result is the most challenging issue, especially when the participants expect SROI greater than $100 \%$ and when the observation coverage involves a huge project with numerous stakeholders. People often exaggerate their own contribution to the team due to natural egocentricity (Schroeder, Caruso, \& Epley, 2016). This fairly widespread phenomenon may occur because they genuinely believe the result was greater, minimizing the contributions of their partner.

The fact is that social action involves the inter-sectoral as well as the intrasectoral, which represents a supply chain where the next project is dependent on the completion of the former one. For example, prior to the Green and Clean Festival, there were some corporate social responsibility programs with social marketing programs on promoting hygiene practices, or initiatives from nonprofit organizations about sanitation and hygiene practices. This means that the communities along a supply chain of social action could exaggerate their claims by failing to separate the positive impacts of other organizations that "unlock" the benefits of the scheme under consideration (Pathak \& Dattani, 2014).

Thirdly, there is an assumption that there is no market failure. This means that the product and innovation are expected to meet the market requirements. The observation occurred at a certain time, while there was a potential risk from environmental turbulence, including market preference, technological changes, competition and policy turbulence. For example, buyers of compost may prefer to buy a certified organic compost, or new technology may produce a substitution product from another waste product. Hence, future research must encourage people to understand that it involves a risk that springs from environmental turbulence.

Fourth, underestimated input value occurred as there were many unmentioned activities that do not bring a direct impact on social benefit. In this case, a folk dancing training activity does not only allow the programme to reach school children but also encourages their parents as well as their extended family members to become involved in the program. Quran praying times also provide a forum that allows the community members to be active. However, the value of such activities is not reliable. Community gardening is also essential to develop social capital, which can enhance neighborhood-wide meetings (Alaimo, Reischi, \& Allen, 2010). 
To develop social innovation does not only require marketing capability but also alliance capability. The value that users derive from many products depends not only on the product's customer benefits but also on its network of users. For example, the community may rely on some research centers or non-profit making organizations to develop the technology for their new product development. As network size is a primary determinant of the value from a network (Afuah, 2013), an open innovation strategy may allow a firm to discover new competitive possibilities, but this may provide potential risk because one firm's positive realization is more likely to coincide with that of another firm (Ross, 2014). Positive assortative matching in firm's size implies that the equilibrium of a matching market enables firms on each side to engage in an alliance in which they maintain high relative bargaining power (Mindruta, Moeen, \& Agarwal, 2016).

Fifth, there is a potential of drop off on account of a reduction in stakeholders' benefits over a four year period. Long ago, before the competition or other development intervention, the observed communities regularly conducted a selfsupport community meeting. The sponsor is essential to foster the performance with donations of tools, seeds or money. However this community meeting is at risk of dissolving when the incentives are withdrawn. This becomes a typical problem for development programs, even under the World Bank (Masuri \& Rao, 2013). The reasons may come from opportunity cost. Hence, future studies on SROI are encouraged to involve opportunity costs, which may impact on the intention of the community to participate.

This study has some limitations that need to be taken into account. First, this study focuses on a community perspective during the observed time. The communities may experience different levels of capability and resources that contribute to the achievement of the program.

Secondly, there is a lack of literature that could provide financial proxy and there is no common accepted method for measuring the values of the social benefits. Although this study indicates that the impact of the Green and Clean Festival was greater than its cost, this does not mean that the program will gain great support and participation from the community.

Lastly, this study concerns one year's activities. This is a snapshot observation. Future studies are encouraged to conduct a longitudinal survey of various case studies. This is expected to provide more opportunities to explore various levels of impact, direct and indirect impact, which have a more far reaching effect on people, organizations, institutions and entities who are not directly engaging with it. They might not even know they are being affected at all, but the "impact" of the activities might be very significant for them. In addition, this study focused 
on value estimation in a one-year observation. Future studies are encouraged to explore the result from longitudinal studies.

\section{Conclusion}

This study contributes to the social exchange theory, which argues that participation springs from individual cost-benefit analysis. The social exchange theory believes that involving various stakeholders to value the result allows the study to legitimize the analysis. The social return is often contested by various programs, time-bound and incomplete, which implies exaggeration. However, the study demonstrates that the participatory approach in assessing the social return on investment supports the effort of the communities, which may impact on the sustainability of the observed activities.

\section{References}

Afuah, A. (2013). Are network effects really all about size? The role of structure and conduct. Strategic Management Journal, 34, 257-273.

Alaimo, K., Reischi, T., \& Allen, J.O. (2010). Community gardening, neighborhood meetings, and social capital. Journal of Community Psychology, 38(4), 497-514.

Altuna, N., Contri, A. M., Dell'Era, C., Frattini, F., \& Maccarrone, P. (2015). Managing social innovation in for-profit organizations: The case of Intesa Sanpaolo. European Journal of Innovation Management, 18(2), 258-280.

Andersén, J., \& Andersén, A. (2014). Deconstructing resistance to organizational change: a social representation theory approach. International Journal of Organizational Analysis, 22(3), 342-355.

Arvidson, M., Battye, F., \& Salisbury, D. (2014). The social return on investment in community befriending. International Journal of Public Sector Management, 27(3), $225-240$.

Berry, T., \& Junkus, J. (2013). Social responsible investing: An investor perspective. Journal of Business Ethics, 112(4), 707-720.

Boxer, P. (2015). Betraying the citizen: Social defence against innovation. Organizational \& Social Dynamics, 15(1), 1-19.

BPS Statistic Bureau. (2016). Surabaya in Figure. Surabaya: Statistic Bureau.

Bunnell, T., Miller, M., Phelps, N., \& Taylor, J. (2013). Urban Development in a Decentralized Indonesia: Two Success Stories? Pacific Affair, 86(4).

Carlon, D., \& Downs, A. (2014). Stakeholder valuing: A process for identifying the interrelationship between firm and stakeholder attributes. Administrative Sciences, 4(2), 137-154. 
Cordeiro, J., \& Tewari, M. (2015). Firm characteristics, industry context, and investor reactions to environmental CSR: A stakeholder theory approach. Journal of Business Ethics, 130(4), 833-849.

Deeming, C., \& Smyth, P. (2015). Social investment after Neoliberalism: Policy paradigm and political platforms. Journal of Social Policy, 44(4), 297-318.

Devezer, B., Sprott, D., Spangenberg, E., \& Czellar, S. (2014). Consumer well-being: Effect of subgoal failures and goal importance. Journal of Marketing, 78(3), 118-134.

Du, H., Li, X., Lin, D., \& Tam, C. C. (2014). Hopelessness, individualism, collectivism, and substance use among young rural-to-urban migrants in China. Health Psychology and Behavioral Medicine, 2(1), 211-220.

Faguet, J.-P. (2014). Decentralization and governance. World Development, 53(10), 2-13.

Fox, J. (2014). Social Accountability: What does the evidence really say? Working paper, The World Bank, Global Partnership for Social Accountability, Washington, DC.

Freeman, E., Harrison, j., Wicks, A., Parmar, B., \& de Colle, S. (2010). Stakeholder Theory: In the State of the Art. Cambridge, UK: Cambridge University Press.

Graham, D. (2006, April 30). Down to earth with Surabaya's first lady. The Jakarta Post.

Jacobs, H. (2013). Co-innovation through multiple social identity processes. European Business Review, 25(1), 42-64.

Jardine, C., \& Whyte, B. (2013). Valuing desistence? A social return on investment case study of a throughcare project for shorterm prisoners. Social and Environmental Accountability Journal, 33(1), 20-32.

Jing, R., Xie, J. L., \& Ning, J. (2014). Commitment to organizational change in a Chinese context. Journal of Managerial Psychology, 29(8), 1098-1114.

Kashif, M., Sarifuddin, S., \& Hassan, A. (2015). Charity donation: intentions and behavior. Marketing Intellegence \& Planning, 33(1), 90-102.

Kurtz, L., \& diBartolomeo, D. (2011). The long-term performance of a social investment universe. Journal of Investing, 20(3), 95-102.

Kwon, S.-W., \& Adler, P. (2014). Social capital: maturation of a field of research. Academy of Management Review, 39(4), 412-422.

Ludwig, S., de Ruyter, K., Friedman, M., Brüggen, E., Wetzels, M., \& Pfann, G. (2013). More than words: the influence of affective content and linguistic style matches in online reviews on conversion rates. Journal of Marketing, 77(1), 87-103.

Masuri, G., \& Rao, V. (2013). Localizing Development: Does Participation Work? Washington, D.C., USA: World Bank.

Michaelides, P., \& Theologou, K. (2010). Tarde's influence on Schumpeter: Technology and social evolution. International Journal of Social Economics, 37(5), 361-373.

Milanov, H., \& Shepherd, D. (2013). The importance of the first relationship: the ongoing influence of initial network on future status. Strategic Management Journal, 34(9), $727-750$. 
Mindruta, D., Moeen, M., \& Agarwal, R. (2016). A two-sided matching approach for partner selection and assessing complementaries in partners' attributes in inter-firm alliances. Strategic Management Journal, 37, 206-231.

Munawar, E. (2013). Injury Time for Indonesia Landfills. Waste Management World. Vienna, Austria: International Solid Waste Association.

Narendra. (2007, August 9). Dyah Katarina Bambang DH Salut SDK Santa Theresia I Surabaya. (T. Hijau, Producer) Retrieved March 28, 2016, from tunashijau.org

Nathan, S., Braithwaite, J., \& Stephenson, N. (2014). The scope and impact of community participation: The views of community representatives in an Australian health service. Journal of Health Organization and Management, 28(3), 405-421.

Nicholls, J. (2014, June 23). People, power, and accountability. Stanford Social Innovation Review.

OECD. (2011). Health at a Glance 2011. Paris: OECD.

Osrom, E. (2009). A Polycentric Approach For Coping With Climate Change. Policy Research Working Papers. Washington, D.C.: World Bank.

Pathak, P., \& Dattani, P. (2014). Social return on investment: three technical challenges. Social Enterprise Journal, 10(2), 91-104.

Paunescu, C. (2014). Current trends in social innovation research: social capital, corporate social responsibility, impact measurement. Management \& Marketing, 9(2), $105-118$.

Phills, J. (2008). Rediscovering Social Innovation. Standford Social Inovation Review, 6(4), 34.

Pratono, A. H., \& Sutanti, A. (2016). The ecosystem of social enterprise: Social culture, legal framework, and policy review in Indonesia. Pacific Science Review B: Humanities and Social Sciences, 2(3), 106-112.

Premakumara, D. (2012). Kitakyushu City's International Cooperation for Organic Waste Management in Surabaya City, Indonesia and Its Replication in Asia Cities. Tokyo: Institute for Global Environmental Strategies.

Ross, D. (2014). Taking a chance: A formal model of how firms use risk in strategic interaction with other firms. Academy of Management Review, 39(2), 202-226.

Rotheroe, N., \& Richards, A. (2007). Social Return on Investment and social enterprise: Transparent accountability for sustainable development. Social Enterprise Journal, 3(1), 31-48.

Schaubroeck, J., Peng, A., \& Hannah, S. (2013). Developing trust with peers and leaders: impacts on organizational identification and performance during entry. Academy of Management Journal, 56(4), 1148-1168.

Schroeder, J., Caruso, E. M., \& Epley, N. (2016). Many hands make overlooked work: Over-claiming of responsibility increases with group size. Journal of Experimental Psychology: Applied, 22(2), 238-246.

Sijabat, R. (2001, November 20). Health fear rise in Surabaya as garbage debate stalls. The Jakarta Post. 
Simpson, R., \& Zimmermann, M. (2013). The Economy of Green Cities: A World Compedium on the Green Urban Economy. London: Springer.

Slack, R., Corlett, S., \& Morris, R. (2015). Exploring employee engagement with (corporate) social responsibility: A social exchange perspective on organizational participation. Journal of Business Ethics, 127(3), 537-548.

Soewondo. (2014). Facts of Indonesia's Health Care Financing. World Health Organization, Country Office for Indonesia. Jakarta: WHO Indonesia.

Sophiaan, A. (2001, November 5). Garbage accumulates in Surabaya. The Jakarta Post.

Tanskanen, K. (2015). Who wins in a complex buyer-supplier relationship? A social exchange theory based dyadic study. International Journal of Operation \& Production Management, 35(4), 577-603.

Taylor, J., \& Bradbury-Jones, C. (2011). International principles of social impact assessment: lessons for research? Journal of Research in Nursing, 16(2), pp. 133-145.

The World Bank. (2015). World Health Organization Global Health Expenditure database. New York: World Bank Group.

Willis, E., Semple, A., \& de Waal, H. (2016). Quantifying the benefits of peer support for people with dementia: A Social Return on Investment (SROI) study. Dementia, $15(2), 1-13$. 


\section{This Journal}

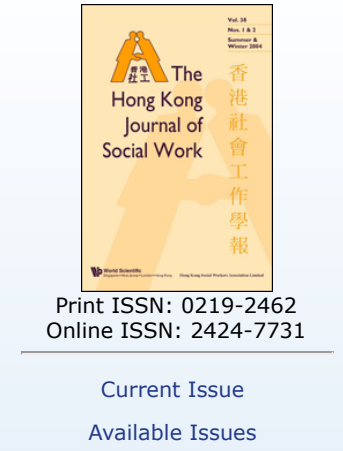

\section{The Hong Kong Journal of Social Work}

\section{Submission Guidelines}

All contributions will be blind reviewed by two reviewers. Editorial Committee reserves the right for final acceptance of manuscript in HKJSW.

The HKJSW does not accept submission that has been previously published, nor manuscript that is under concurrent consideration of another publication.

Upon completing submission of a manuscript, it implies that the Author agrees to the binding that if the manuscript is accepted for publication, copyright of the article should be assigned exclusively to the HKJSW.

Starting from 2011 onward, manuscripts should be submitted through

http://www.hkswa.org.hk/hkjsw. Screenshots of the five-step submission process can be viewed http://www.hkswa.org.hk/hkjsw/5step_submission.htm.

\section{Step 1}

1.1. There are four major sections of the Journal: Journal Article, Professional and Practice Forum, Book Review and Research Brief. Author should select the appropriate section for the submission in this Step. Lengths of manuscripts (excluding references) for each section are as follow:

\begin{tabular}{|l|c|c|}
\hline \multirow{2}{*}{ Section } & \multicolumn{2}{c|}{ Word Limit } \\
\cline { 2 - 3 } & English manuscript & Chinese manuscript \\
\hline Journal Article & 4000 & 8000 \\
\hline Professional and Practice Forum & 3000 & 5000 \\
\hline Book Review & 1500 & 2000 \\
\hline Research Brief & 1500 & 2000 \\
\hline
\end{tabular}

1.2. Author should indicate that the submission is ready to be considered by the HKJSW by checking off the listed items.

1.3. Author may input additional comment for the editor.

\section{Step 2}

2.1. Submitted manuscript is to be uploaded in this Step.

2.2. Author(s) should remove any personally indentifiable information in the manuscript.

2.3. Submitted manuscript should be prepared in OpenOffice, Microsoft Word, RTF, or WordPerfect document file format. It must also conform to the conventions of style and format described in the Publication Manual of the American Psychological Association (5th ed., 2001).

\section{Step 3}

Author should input information as requested in this Step, including author(s) details, affiliation(s), email address, as well as the title, abstract and keywords of the manuscript.

\section{Step 4}

Author may upload any supplementary file in this Step, such as files containing tables and figures.

\section{Step 5}

Author can check all the files uploaded. Submission process is completed upon author's click of the "Finish Submission" button. The system will also send an auto-email notification to confirm the submission.

For enquiries, please contact our Associate Editor Dr. Anna Choi:

phone: (852) 3917-2079

fax: (852) 2858-7604

email: annachoi@socwork.hku.hk

\section{來稿稿例}

所有來稿均由兩位評審委員不註名審核。文稿接受與否由評審委員會作最後決定。 
本學報並不接受已經出版之文稿，亦不接受一稿兩投或多投。

完成投稿程序亦即表示作者同意，所投的文稿一旦獲本學報接納刊登，版權屬本學報。

自2011 年起, 來稿必須透過 香港社會工作學報網上投稿系統 (HKJSW Online Submission System)遞交。作 者可於此處了解投稿五個步驟的圖示。

第一步

1.1. 學報共分爲四個部份：原創文章、專業及實務論壇、書評及研究簡報。作者須按指示清楚註明投稿那一個 部份。各部份來稿的字數限制如下 參考書目字數除外:

\begin{tabular}{|l|c|c|}
\hline \multirow{2}{*}{ 部份 } & \multicolumn{2}{c|}{ 字數限制 } \\
\cline { 2 - 3 } & 英文來稿 & 中文來稿 \\
\hline 原創文章 & 4000 & 8000 \\
\hline 專業及實務論壇 & 3000 & 5000 \\
\hline 書評 & 1500 & 2000 \\
\hline 研究簡報 & 1500 & 2000 \\
\hline
\end{tabular}

1.2. 作者須勾選所列出的項目, 表示文稿學報的投稿要求。

1.3. 作者可按需要填寫按語予編輯參考。

第二步

2.1. 作者須按指示上傳文稿檔。

2.2. 作者必須移除來稿中所有會顯示其身份的資訊。

2.3. 文稿應以 OpenOffice, Microsoft Word, RTF, 或 WordPerfect 文件檔案格式記錄。此外, 文稿必須符 合美國心理學會出版手冊 年第五版所指定的文體和格式慣例。

第三步

作者須按指示填寫個人資料、所屬機關、電郵，以及文章題目、摘要及關鍵詞等。

第四步

作者可於此上傳補充檔案, 如圖表及圖像檔等

\section{第五步}

作者可於此檢視所有已上傳的檔案，並按 "Finish Submission" 按鈿完成整個投稿程序。另系統會發出自動電 郵確認完成程序。

如有查詢, 請聯絡 蔡惠敏博士:

電話: (852) 3917-2079

傳真: (852) 2858-7604

電郵: annachoi@socwork.hku.hk

\section{Site Tools}

Recommend to library

Alert me on new issues

Add journal to favorites

RSS (What is this?)

\section{Most Read Articles}

- THE ADVENT OF MANAGERIALISM IN SOCIAL WELFARE: THE CASE OF HONG KONG

Vol. 36 , Iss. 01n02

SOCIAL WITHDRAWAL

OF YOUNG PEOPLE IN

HONG KONG: A

SOCIAL EXCLUSION

PERSPECTIVE

Vol. 40 , Iss. $01 \mathrm{n} 02$

- 社會工作的「社會」涵

義: 重拾社會工作中的社

會本質

Vol. 44 , Iss. 01

- 社區工作：意義重塑與展

Vol. 45 , Iss. $01 \mathrm{n} 02$

-「去權」與「充權」:

- 社工專業本質的反思

Vol. 48 , Iss. $01 \mathrm{n} 02$

See more...

\section{Related}

Related Journals

Jit Journal of Socia

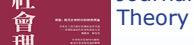


Related Books

Reconstitution of

Social Work

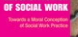

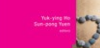

Social Services

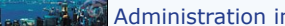

Hong Kong

ECONOMIC Economic
FREEDOM

Lessons of Hong

L. Kong

The Mirror of

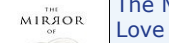

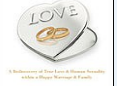

Related Links

Social Sciences Journals

Global Publishing

Global Network for Chinese Professionals 


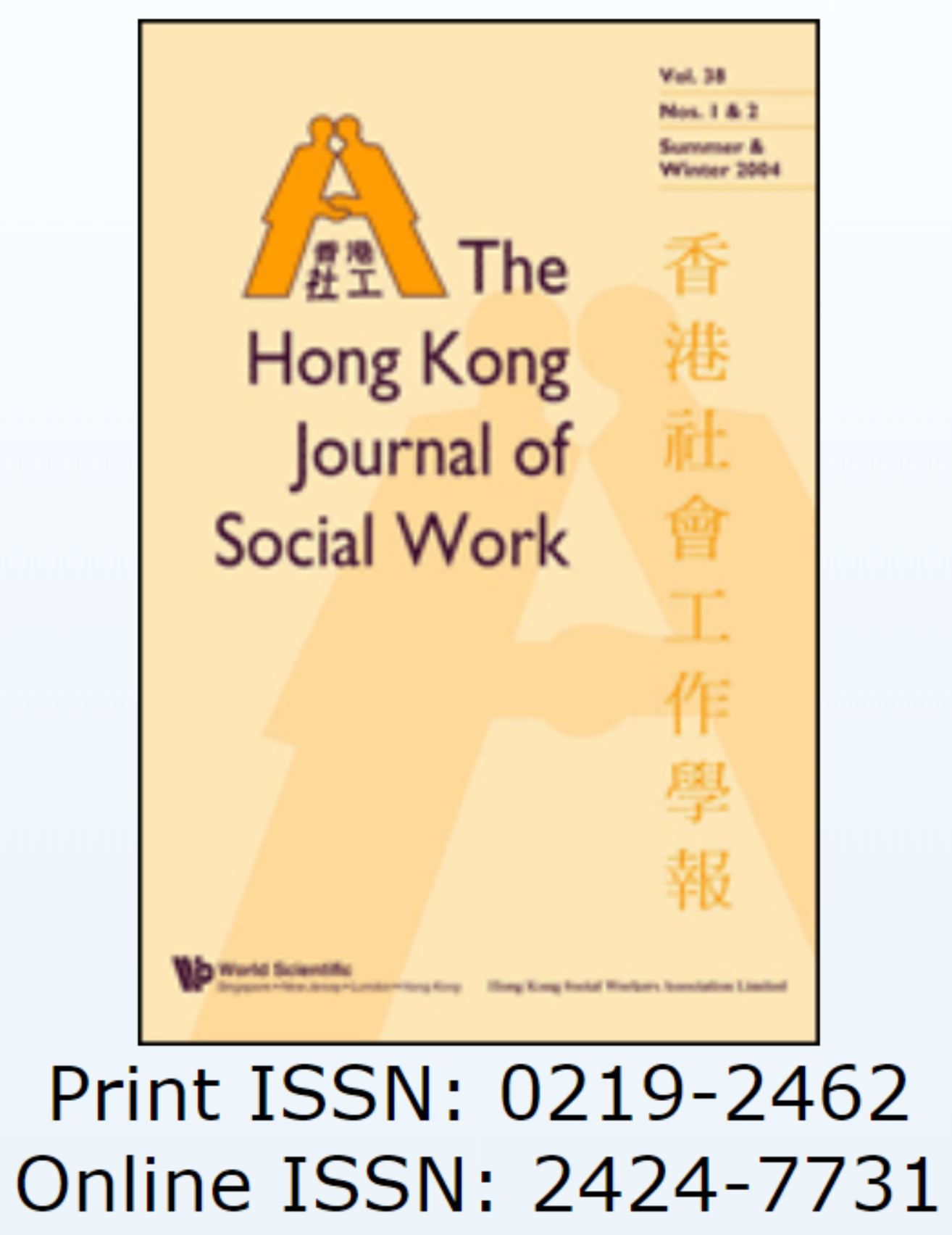


Home > All Publications > All Journals > The Hong Kong Journal of Social Work > HKJSW Editorial Board

\section{This Journal}

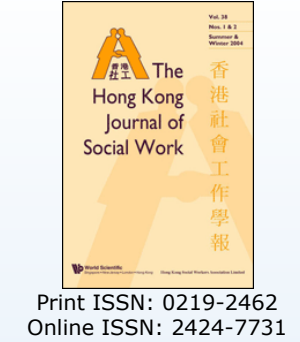

Current Issue

Available Issues

\section{The Hong Kong Journal of Social Work}

\section{Editorial Board}

\section{Chief Editor 總編輯}

CHOI Wai Man, Anna 蔡惠敏

The University of Hong Kong

\section{Managing Editor 執行編輯}

WANG Julia Shu-Huah 汗書華

The University of Hong Kong

\section{Associate Editor 副編輯}

CHUI Wing Tak, Ernest 徐永德

The University of Hong Kong

\section{Editorial Committee 編輯委員會}

CHEUNG Oi-ngor, Sandra 張愛娥

CHIU Yu-lung, Marcus 趙雨龍

LEUNG Lai-ching 梁麗清

NG Hang-sau 伍杏修

NGAI Ngan-pun 魏雁濱

WONG Wai-mui, Nancy 王惠梅

YUK Tak-fun, Alice 郁德芬

\section{International Consulting Editors}

Ada Mui (Columbia University, USA)

Alan Walker (University of Sheffield, UK)

Bruce Jansson (University of South California, USA)

Chang Chen Cheng (Fu Jen Catholic University, Taiwan)

David Howe (University of East Anglia, UK)

Elizabeth Ozanne (University of Melbourne, Australia)

Francis Yuen (California State University, Sacramento, USA)

Francis Yuen (California State University, Sacramento, USA)

Jacques Boulet (Borderlands Co-operative Ltd., Australia)
James Midgley (University of California at Berkeley, USA)

Jan Fook (Deakin University, Australia)

John Forester (Technion, Israel)

Shen Chiung-tao (National Taiwan Univerity)

June Thoburn (University of East Anglia, UK)

Kate Woodthorpe (The Open University, UK)

Kathy Boxall (University of Sheffield, UK)

Lee Mo Yee (The Ohio State University, USA)

Mark Drakeford (University of Wales, UK)

Michar Hill (University of Brighton, UK)

Monit Cheung (University of Houston, USA)

Monit Cheung (University of Houston, USA)

Plive Stevenson (University of Nottingham,

Patrick Leung (University of Houston, USA)

Peter Huxley (Swansea University, UK)
Rosaleen Ow (National University of Singapore)

Rosemary Sarri (University of Michigan, USA)

Sherrill Evans (Swansea University, UK)

Stanley Witkin (University of Vermont, USA)

Wang Sibin (Peking University, China)

Wang Tsen-Yung (National Yang Ming University, Taiwan)

\section{Site Tools}

Recommend to library Alert me on new issues Add journal to favorites RSS (What is this?)

5 Most Read Articles

- THE ADVENT OF MANAGERIALISM IN SOCIAL WELFARE: THE CASE OF HONG KONG

Vol. 36 , Iss. 01n02

- SOCIAL WITHDRAWAL

OF YOUNG PEOPLE IN

HONG KONG: A

SOCIAL EXCLUSION 
Vol. 40 , Iss. $01 \mathrm{n} 02$

- 社會工作的「社會」涵

義: 重拾社會工作中的社

會本質

Vol. 44 , Iss. 01

- 社區工作: 意義重塑與展

望

Vol. 45 , Iss. $01 \mathrm{n} 02$

- 「去權」與「充權」:

Vol. 48 , Iss. $01 \mathrm{n} 02$

See more...

\section{Related}

Related Journals

部 Journal of Social

曾 = $=$ Theory

論

\section{Related Books}

Reconstitution of

Social Work

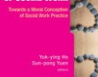

Social Services

and Administration in

Hong Kong

\section{$\begin{array}{ll}\text { ECONOMIC } & \text { Economic } \\ \text { FREEDOOM } \\ \text { FREN Freedom: }\end{array}$}

Lessons of Hong

tare Kong

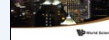

\begin{tabular}{|l} 
TIRAOR \\
MIS Mirror of \\
Love
\end{tabular}

LOVE LOV

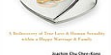

Related Links

Social Sciences Journals

Global Publishing

Global Network for Chinese

Professionals 
Home $>$ All Publications $>$ All Journals $>$ The Hong Kong Journal of Social Work $>$ Available Issues $>$ Volume 51, Issue 01n02

\section{This Issue}

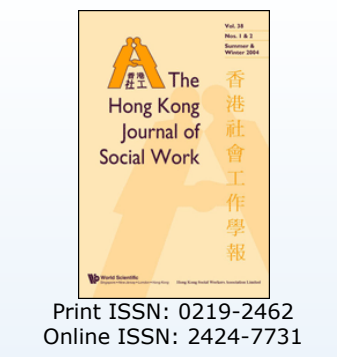

Current Issue

Available Issues

\section{The Hong Kong Journal of Social Work}

Volume: 51, Number: 01 n02 (Summer \& Winter 2017)

Add to Favorites | Citation Alert | View Abstracts | Send to Citation Mgr

Select All

iii EDITORIAL

Zeno LEUNG

https://doi.org/10.1142/S021924621700002X

Abstract | PDF (278 KB) | PDF Plus (279 KB)

3 SOCIAL CONFLICT AND SOCIAL INNOVATION

NGAI KUEN ALVIN KWOK

https://doi.org/10.1142/S0219246217000031

Abstract | PDF (562 KB) | PDF Plus (569 KB)

27 INNOVATIONS IN FINANCIAL INCLUSION OF THE URBAN POOR: A MODEL OF RAHAT CREDIT COOPERATIVE SOCIETY, INDIA ANJALI KULKARNI

https://doi.org/10.1142/S0219246217000043 Abstract | PDF (436 KB) | PDF Plus (440 KB)

51 GENDERED BOP HYGIENE MARKETS IN RURAL INDIA: A CASE STUDY OF SOCIAL ENTREPRENEURSHIP AND SOCIAL INNOVATION SUKHPAL SINGH

https://doi.org/10.1142/S0219246217000055 Abstract | PDF (368 KB) | PDF Plus (372 KB)

73 SHARED VALUE STRATEGY: A SUSTAINABLE STAKEHOLDER APPROACH TO SOCIO-ECONOMIC DEVELOPMENT SHELEN WAI HAN HO

https://doi.org/10.1142/S0219246217000067 Abstract | PDF (930 KB) | PDF Plus (676 KB)

SOCIAL RETURN ON INVESTMENT FOR COMMUNITY-BASED ENTERPRISE IN SURABAYA CITY

ALUISIUS HERY PRATONO, SUYANTO, DEDDY MARCIANO, CHRISTIAN ZURBRÜGG

https://doi.org/10.1142/S0219246217000079

Abstract | PDF (366 KB) | PDF Plus (394 KB)

115 SOCIAL ENTERPRISE AS A MECHANISM OF YOUTH EMPOWERMENT

YANTO CHANDRA, SHANG LIANG

YANTO CHANDRA, SHANG LIANG
https://doi.org/10.1142/S0219246217000080

https://doi.org/10.1142/S0219246217000080
Abstract | PDF (623 KB) | PDF Plus (670 KB)

145 EDUCATING SOCIAL ENTREPRENEURSHIP: INSIGHTS FROM THE HIGHER EDUCATION COURSES IN HONG KONG KIN YUEN RAYMOND TAM

https://doi.org/10.1142/S0219246217000092

Abstract | PDF (355 KB) | PDF Plus (364 KB) 